\title{
ANTIFUNGAL ACTIVITY AND ULTRASTRUCTURAL ALTERATIONS IN Pseudocercospora griseola TREATED WITH ESSENTIAL OILS
}

\author{
Atividade antifúngica e alterações ultraestruturais em Pseudocercospora griseola \\ tratado com óleos essenciais
}

\author{
Julián Mauricio Ágredo Hoyos ${ }^{1}$, EduardoAlves ${ }^{2}$, Luciane Cristina Rozwalka ${ }^{3}$, \\ Elaine Aparecida de Souza ${ }^{4}$, Walmes Marques Zeviani ${ }^{5}$
}

\begin{abstract}
Pseudocercospora griseola, the etiologic agent of angular leaf spot of common bean (Phaseolus vulgaris), is an important disease in all bean-producing regions worldwide and may cause extremely high yield losses. The control of this disease is made more difficult by the pathogen's genetic variability and the inefficiency of fungicides. In this study, of 26 essential oils tested at different concentrations, 25 demonstrated efficiency in affecting the germination of strains 63-31 and 63-63 of the pathogen, reaching inhibition levels of between 80\% and $100 \%$. Cymbopogon citratus and Cymbopogon martinii inhibited conidia germination at all concentrations; Eugenia caryophyllata, Cinnamomum sp., Thymus vulgaris, Matricaria recutita, Cordia verbenacea, Origanum vulgare, Cymbopogon nardus, at 0.1 and $0.5 \%$; and Zingiber officinale, Mentha arvensis, Chamaecyparis pisifera, Lavandula officinalis, Ocimum basilicum, Pimpinella anisum, Ocimum selloi, Baccharis dracunculifolia, Laurus nobilis, Citrus sinensis, Melaleuca alternifolia and Eucalyptus globulus, at $0.5 \%$. The main constituents identified were cinnamaldehyde in Cinnamomum sp.; eugenol in E. caryophyllata; trans- $\beta$-farnesene in M. recutita; pulegone in $C$. verbenacea; thymol in T. vulgaris; geranial and neral in $C$. citratus, and geraniol in $C$. martini. Through transmission electron microscopy (TEM), it was verified that $C$. citratus, $C$. martini and $E$. caryophyllata presented direct fungitoxic action on $P$. griseola, causing severe damage to the cellular ultrastructure of the conidia, invalidating germination. These results indicated that essential oils are a promising alternative strategy for the control of angular leaf spot in bean, representing less risk to human health and the environment.
\end{abstract}

Index terms: Angular leaf spot, transmission electron microscopy, alternative control of plant disease.

\section{RESUMO}

Pseudocercospora griseola, agente etiológico da mancha angular do feijoeiro comum (Phaseolus vulgaris), é uma doença importante nas regiões produtoras de feijão em todo o mundo e pode causar perdas de produtividade extremamente elevados. O controle dessa doença é dificultado pela variabilidade genética do patógeno e da ineficiência de fungicidas. Neste estudo, de 26 óleos essenciais testados em concentrações diferentes, 25 demonstraram eficiência em inibir a germinação das linhagens 63-31 e 63-63 do agente patogênico, atingindo níveis de inibição entre $80 \%$ e $100 \%$. Cymbopogon citratus e Cymbopogon martini inibiram a germinação de conídios em todas as concentrações; Eugenia caryophyllata, Cinnamomum sp., Thymus vulgaris, Matricaria recutita, Cordia verbenacea, Origanum vulgare, Cymbopogon nardus, em 0,1 e 0,5\%, e Zingiber officinale, Mentha arvensis, Chamaecyparis pisifera, Lavandula officinalis, Ocimum basilicum, Pimpinella anisum, Ocimum selloi, Baccharis dracunculifolia, Laurus nobilis, Citrus sinensis, Melaleuca alternifolia e Eucalyptus globulus, em 0,5\%. Os principais constituintes identificados foram cinamaldeído em Cinnamomum sp.; Eugenol em E. caryophyllata; trans- $\beta$-farneseno em $M$. recutita; pulegona em $C$. verbenacea; timol em $T$. vulgaris; geranial e neral em $C$. citratus e geraniol em C. martini. Através de microscopia eletrônica de transmissão (TEM), verificou-se que C. citratus, C. martini e E. caryophyllata apresentaram ação antifúngica direta sobre $P$. griseola, causando graves danos na ultraestrutura celular dos conídios, invalidando a germinação. Esses resultados indicaram que os óleos essenciais são uma estratégia alternativa promissora para o controle da mancha angular do feijoeiro, o que representa menos risco para a saúde humana e ao ambiente.

Termos para indexação: Mancha angular, microscopia eletrônica de transmissão, controle alternativo de doenças de plantas.

\section{(Received in april 13, 2012 and approved in may 21, 2012)}

\section{INTRODUCTION}

Angular leaf spot (ALS), caused by Pseudocercospora griseola (Sacc.) Crous \& U. Braun, is the most widespread disease in all bean-producing regions worldwide. According to the Commonwealth Mycological
Institute (CMI), this disease occurs in more than 60 countries (SARTORATO; RAVA, 1994) and, under favorable environmental conditions, yield losses may reach 80\% (JESUS-JÚNIOR et al., 2001; STENGLEIN et al., 2003; PAULA-JÚNIOR; ZAMBOLIM, 2006). Although application of fungicides is the primary measure taken to

\footnotetext{
${ }^{1}$ Universidade Federal de Lavras/UFLA - Departamento de Fitopatologia/DFP - Lavras - MG - Brasil

2Universidade Federal de Lavras/UFLA - Departamento de Fitopatologia/DFP - Cx. P. 3037 - 37200-000 - Lavras - MG - Brasil - ealves@dfp.ufla.br

3Universidade Federal do Paraná/UFPR - Curitiba - PR - Brasil

${ }^{4}$ Universidade Federal de Lavras/UFLA - Departamento de Biologia/DBI - Lavras - MG - Brasi

${ }^{5}$ Universidade Federal do Paraná/UFPR - Laboratório de Estatística e Geoinformação - Curitiba - PR - Brasil
} 
control plant diseases, their continuous and indiscriminate use has caused contamination by waste, environmental pollution and the selection of resistant populations of pathogens. Chemical control carries considerable environmental and financial costs (MIKLAS et al., 2006). Due to the high genetic variability of $P$. griseola (BROCK, 1951; PYNDJI, 1993; PASTOR-CORRALES et al., 1998; OROZCO; ARAYA, 2005; STENGLEIN; BALATTI, 2006; SILVA, et al., 2008), genetic control through the use of resistant cultivars is very difficult.

The inefficiency of pesticides in the control of ALS and the lack of resistant cultivars, as well as market demands in food production and the need to achieve environmental sustainability, food security and economic viability, have all made the use of technology that is nonaggressive to the environment and human health into a major challenge for bean producers. Considering these problems, it has become vital to develop strategies based on the rational use of fungicides or to replace them with alternative products (CHRISTIAN; GOGGI, 2008; GHINI; KIMATI, 2000). Essential oils have shown biological activity that may offer an alternative strategy in the control of plant pathogens (MIHALIAK et al., 1991; STANGARLIN et al., 1999; ISMAN, 2000; KOTZEKIDOU et al., 2008) due to fungitoxic action (FUORI et al., 2000; BONALDO et al., 2004; BANG, 2007) or by inducing resistance in plants (SCHWAN-ESTRADA, 2003; QUINTANILLA et al., 2002; PEREIRA et al., 2011).

The essential oils extracted from medicinal, aromatic and ornamental plants have shown efficiency in controlling plant pathogens (SHAHI et al., 2003; SOYLU et al., 2006; LEE et al., 2007; BARRERA-NECHA et al., 2008). The effects of essential oils have been studied at the ultrastructural level for some pathogens (ZAMBONELLI et al., 1996; RASOOLI et al., 2006; ROZWALKA et al., 2010). However, there are no reports about the antifungal activity and the mode of action of essential oils on $P$. griseola. This study aimed to evaluate (i) the antifungal activity of 26 essential oils on germination of $P$. griseola conidia, strains 63-31 and 63-63; (ii) the effect of the essential oils of Cymbopogon martini, Eugenia caryophyllata and Cymbopogon citratus on conidia at ultrastructural level by transmission electron microscopy (TEM), and (iii) to identify the chemical constituents of essential oils with fungitoxic activity against this plant pathogen.

\section{MATERIALS AND METHODS}

\section{Fungal isolates}

Two monosporic isolates of $P$. griseola were employed, classified as pathotypes 63-31 and 63-63, from the mycology collection of the Institute of Biotechnology applied to Agriculture (BIOAGRO) at the Federal University of Viçosa (Viçosa, Minas Gerais State, Brazil). Conidia were obtained by culturing the fungus on bean leaf-dextrose-agar medium in a growth chamber (Fanem, São Paulo, Brazil) at $24 \pm 2^{\circ} \mathrm{C}$. After approximately 15 days, spore suspension was prepared by adding 5-10 mL of sterile distilled water to each Petri dish and scraping the surface of the culture with a spatula.

\section{Essential oils}

The essential oils extracted from 26 medicinal, ornamental, aromatic, or forest species representative of the families Apiaceae (Pimpinella anisum L.), Asteraceae (Baccharis dracunculifolia DC., Matricaria recutita L.), Boraginaceae (Cordia verbenacea DC.), Cupressaceae (Chamaecyparis pisifera (Siebold \& Zucc.) Endl., Chamaecyparis plumosa Hort. ex Beissn.), Lamiaceae (Lavandula officinalis Chaix ex Vill., Mentha arvensis L., Ocimum basilicum L., Ocimum selloi Benth., Origanum vulgare L., Rosmarinus officinalis L., Thymus vulgaris L.), Lauraceae (Cinnamomum sp., Laurus nobilis L.), Myrtaceae (Corymbia citriodora (Hook.) K.D. Hill \& L.A.S. Johnson, Eucalyptus globulus Labill., Eugenia caryophyllata Thunb., Melaleuca alternifólia Cheel), Poaceae (Cymbopogon citratus (DC) Stapf., Cymbopogon martini (Roxb.) Wats., Cymbopogon nardus (L.) Rendle), Rutaceae (Citrus limon (L.) Burm.f., Citrus sinensis (L.) Osbeck.), Verbenaceae (Lippia citriodora Kunth) e Zingiberaceae (Zingiber officinale Roscoe).

Essential oils from L. officinalis, O. selloi, $O$. vulgare and Cinnamomum sp. were extracted by hydrodistillation for $3 \mathrm{~h}$ in a Clevenger-type apparatus. Flowers and leaves from $L$. officinalis, and leaves from $O$. selloi and $O$. vulgare were collected at the Medicinal Plants Nursery of the Agricultural Department, Federal University of Lavras, Minas Gerais State, Brazil, at vegetative stage, and cinnamon bark was purchased in a natural store in Lavras city. The remaining essential oils were supplied by Chamel Industry and Natural Products Commerce, Paraná State, Brazil (2010). All essential oils used in this work were kept in amber flasks and stored under refrigeration at $0^{\circ} \mathrm{C}$.

\section{Screening the essential oils with in vitro antifungal activity}

A total of $40 \mu \mathrm{L}$ of essential oils at $0.04 \%, 0.2 \%$ and $1.0 \%$ and $40 \mu \mathrm{L}$ of aqueous conidial suspension $(2 \mathrm{x}$ $10^{4}$ conidia. $\mathrm{mL}^{-1}$ ) prepared from 15-day-old cultures of strains 63-31 and 63-63 were placed inside each well of a 
96-well plate. This mixture resulted in the final concentrations at $0.02 \%\left(200 \mu{\mathrm{L} . \mathrm{L}^{-1}}^{-1}, 0.1 \%\left(1000 \mu{\mathrm{L} . \mathrm{L}^{-1}}^{-1}\right)\right.$ and $0.5 \%\left(5000 \mu{\mathrm{L} . \mathrm{L}^{-1}}^{-1}\right.$. These treatments were prepared using sterile distilled water with Tween 20 at $1.0 \%$. Sterile distilled water $(40 \mu \mathrm{L})$ mixed with conidial suspension was used as control. In previous germinations tests comparing germination in water and water plus Tween-20 a $1.0 \%$, it was observed that Tween showed non-toxic effects in both strains of pathogen. After 20 hours of incubation at $24 \pm 2^{\circ} \mathrm{C}$ and $12 \mathrm{~h}$ photoperiod, germination was interrupted by addition of $20 \mu \mathrm{L}$ of lactoglycerol cotton blue. The percentage of germination was estimated by counting 50 randomly chosen conidia in 6 wells, totaling 300 conidia per treatment, under a light microscope. Conidia presenting differentiated germ tubes, independently of their size, were considered germinated. The experiment were carried out in a completely randomized design, as a factorial 2 x 3 x 3 (strains x oil x concentrations) $\times 6$ repetitions. Each well of the plate was an experimental unit.

\section{Chemical composition of essential oils}

C. martini (0.144 mg), M. chamomilla $(0.127 \mathrm{mg})$, E. caryophyllata $(0.200 \mathrm{mg})$, T. vulgaris $(0.147 \mathrm{mg}), C$. verbenacea $(0.179 \mathrm{mg})$, C. citratus $(0.160 \mathrm{mg})$ and Cinnamomum sp. $(0.118 \mathrm{mg})$ were dissolved in $0.5 \mathrm{~mL}$ of dichloromethane $\left(\mathrm{CH}_{2} \mathrm{Cl}_{2}\right)$. These oils showed antifungal activity of more than $90 \%$, when tested at $0.1 \%$. One microliter of diluted essential oils was injected in gas chromatography coupled with mass spectrometry (GCMSQP2010 Plus, Shimadzu). The gas chromatography operated with ultra pure helium as the carrier gas at a flow rate of $1.8 \mathrm{~mL} \cdot \mathrm{min}^{-1}$ and the separation was done on an Equity-5 capillary column ( $30 \mathrm{~m}$ x $0.22 \mathrm{~mm}$ I.D with $0.25 \mu \mathrm{m}$ film thickness), with column oven at $60^{\circ} \mathrm{C}$ for $2 \mathrm{~min}$, heating at $3^{\circ} \mathrm{C}$. $\mathrm{min}^{-1}$ up to $240^{\circ} \mathrm{C}$, remaining at $240^{\circ} \mathrm{C}$ for $15 \mathrm{~min}$. The temperature of the injector was $220^{\circ} \mathrm{C}$, split injection $1: 15$, manual injection, time run of $77 \mathrm{~min}$. The mass spectrometry used a GC-MS interface, at $250^{\circ} \mathrm{C}$, with ion source at $200^{\circ} \mathrm{C}$ and electron impact ionization at $70 \mathrm{eV}$. The compounds in essential oils were identified by comparing the similarity index of the mass spectra of relative area (\%) with the data available in the library (Wiley 8) of GCMS.

\section{Transmission electron microscopy (TEM) preparation}

A conidial suspension $\left(2 \times 10^{4}\right.$ conidia. $\left.\mathrm{mL}^{-1}\right)$ of strains 63-31 and 63-63, prepared in sterile distilled water with Tween 20 at $1.0 \%$, was mixed with $0.5 \mathrm{~mL}$ of the solutions of $0.2 \%$ essential oils of C. martini, $E$. caryophyllata and C. citratus to obtain a final concentration of $0.1 \%$. For the control, $0.5 \mathrm{~mL}$ conidial suspensions were mixed with $0.5 \mathrm{~mL}$ of sterile distilled water. The treatments remained under agitation in an Orbital Shaker at $100 \mathrm{rpm}$ and an average temperature of $25 \pm 2^{\circ} \mathrm{C}$ and, after $24 \mathrm{~h}$, were centrifuged for $3 \mathrm{~min}$ at 6000 rpm, forming conidial masses. The masses were fixed in modified Karnovsky solution (glutaraldehyde at $2.5 \%$, formaldehyde at $2.5 \%$ in sodium cacodylate buffer at 0.05 $\mathrm{M}, \mathrm{pH} 7.2$, and calcium chloride at $0.1 \mathrm{M}$ ) and kept in the refrigerator for $24 \mathrm{~h}$ (primary fixation). To form pellets, the conidial masses fixed in Karnovsky were centrifuged for $3 \mathrm{~min}$ at $6000 \mathrm{rpm}$. The supernatant was discarded, and the agarose gel at $1.0 \%$ was heated to about $45^{\circ} \mathrm{C}$ and mixed with the pellets. The blocks of agarose formed were washed three times for $10 \mathrm{~min}$ in sodium cacodylate buffer at $0.05 \mathrm{M}$, for post-fixation in osmium tetroxide at $2 \%$ in the hood. After a $4 \mathrm{~h}$ period, the blocks were washed three times in distilled water and submitted to contrast en bloc in an aqueous solution of uranyl acetate at $0.5 \%$ for one night in the refrigerator. The dehydration was done in a graded acetone series at concentrations of 25, 50, 75, 90 and $100 \%$ for 10 min each, except at $100 \%$, which was dehydrated 3 times for 10 min each time.

Subsequently, the blocks were submitted to the embedding process, with the acetone being replaced by resin in an increasing gradient, remaining $8 \mathrm{~h}$ in Spurr resin $(30 \%)$ and acetone $(70 \%), 8 \mathrm{~h}$ in Spurr resin $(70 \%)$ and acetone $(30 \%)$ and twice for $24 \mathrm{~h}$ in pure Spurr resin $(100 \%)$ at room temperature. Samples were transferred to silicone molds, prepared in advance and containing half of the volume with polymerized Spurr resin (100\%), and covered with pure Spurr resin; these then remained in an oven at $70^{\circ} \mathrm{C}$ for $48 \mathrm{~h}$ for polymerization. The blocks were trimmed with razor blades to remove the excess resin and to obtain a trapezoidal shape. Semithin sections $(0.5 \mathrm{~mm})$ were made on a Reichert-Jung (Ultracut E) ultramicrotome with a glass knife, collected with a gold ring and placed on glass slides. These were then dried on a metal plate at about $60^{\circ} \mathrm{C}$, covered with toluidine blue stain, heated on a metal plate until the formation of a gold border, washed with distilled water, dried on a hot plate and visualized by light microscopy for localization of fungal structures of interest and orientation of the ultrathin sections. The ultrathin sections (> $100 \mathrm{~nm}$ ) were made with a diamond knife, collected on copper grids (300 mesh) previously coated with Formvar film, post-contrasted with aqueous solution of uranyl acetate $(2 \%)$ and lead citrate (3\%) (Reynolds, 1963) for $3 \mathrm{~min}$ on each, and washed with 
distilled water. For each treatment, the test was repeated twice and at least two blocks per replicate were examined. The observation of the samples and the recording of the images were performed in a Zeiss EM 109 transmission electron microscope operating at $80 \mathrm{kv}$.

\section{Statistical analysis}

Data analysis was done using generalized linear models (GLMs), assuming a binomial distribution logit link function. The linear predictor was represented by $\log \left[p_{i} /\left(1-p_{i}\right)\right]=\beta_{0 i}+\beta_{1 i} \cdot \sqrt{ } c$, where $p_{i}=$ probability of germination inhibition of conidia treated with essential oil $i(i=1,2, \ldots, 26)$ at concentration $c(c=0.02,0.1$ and $0.5 \%$ ) and $\beta_{0 i}$ and $\beta_{1 i}$ are parameters that bring form to a relationship. The inferences were conducted considering the parameter of overdispersion $(\phi)$ estimated by Pearson residues. All analyzes were performed in $\mathrm{R}$ environment (2.15.0) for statistical computing $\mathrm{R}$ Development Core Team, 2012.

\section{RESULTS AND DISCUSSION}

\section{Antifungal activity of essential oils on germination of $P$. griseola strains, in vitro}

The results of analysis of deviance showed significant interaction between treatments and concentrations of the essential oils, indicating that differences in the percentage of germination occurred in function of the essential oil and concentrations used. So studies were done separately for each pathogen strain. The antifungal activity of essential oils in the germination of $P$. griseola strains, expressed by the percentage of conidial germination inhibition, was calculated based on average number of conidia that germinated from each strain, 63-31 (46.67) and 63-63 (31.75) and the untreated control (Table 1).

Essential oils of $C$. citratus, $C$. martini and $E$. caryophyllata were more effective than the other treatments, showing at least $98 \%$ inhibition of conidial germination of strains 63-31 and 63-63 of $P$. griseola at all tested concentrations. At $0.1 \%, C$. citratus, $C$. martini, $E$. caryophyllata, Cinnamomum sp., T. vulgaris, M. recutita and $C$. verbenacea also showed antifungal activity against both strains. The average germination inhibition values were higher than $93.57 \%$. At $0.02 \%$, conidia germination of strain 63-63 was almost totally inhibited by $C$. citratus, $C$. martini, E. caryophyllata and Cinnamomum sp. However, these two last essential oils did not show the same efficiency against strain 63-31, for which they only reduced inhibition to approximately $50 \%$. Adifference in inhibition response of the two pathogen strains was also observed more effectively on conidia treated with $M$. arvensis, $Z$. officinale, C. pisifera, L. officinalis and B. dracunculifolia at $0.1 \%$ and $C$. plumosa, R. officinalis and L. citriodora at $0.5 \%$. The regression model allows us to observe these differences (Figure 1).

It is also possible to observe that increasing the concentration of essential oil of C. citriodora and C. limon did not result in greater inhibition of the pathogen strains. At $0.5 \%$, of the 26 essential oils screened, 21 promoted inhibition of conidial germination between 86 to $100 \%$ for both strains of the pathogen (Table 2).

At all the tested concentrations, some essential oils stimulated conidial germination of both strains, expressed by the negative sign. C. nardus $(0.02 \%), Z$. officinale $(0.02 \%), R$. officinalis $(0.1 \%)$ and $C$. limon $(0.1 \%, 0.02 \%$ and $0.5 \%)$ were the essential oils that most stimulated conidial germination of strain 63-63 (Table 1). Based on the estimated coefficients of the logistic regression model, by increasing the concentration of $E$. caryophyllata and Cinnamomum sp. from 0.02 to 0.03 and $0.06 \%, M$. arvensis, $Z$. officinale, $O$. vulgare and $C$. nardus from 0.1 to $0.41,0.27,0.13$ and $0.14 \%$, respectively, the conidial germination inhibition of strain 63-31 could be $95 \%$. In this study, it was observed that increasing the concentration of most essential oils promoted their enhanced antifungal activity on $P$. griseola strains. However, the inhibitory effect promoted by essential oils was different for the two strains of the pathogen. Greater conidial germination inhibition was observed for strain 63-63, which is reported to be more aggressive than 63-31 in bean production in Brazil (NIETSCHE et al., 2001; DAMASCENO-SILVA et al., 2008).

\section{Chemical composition of essential oils}

Identification and quantification of the main chemical constituents of essential oils can be seen in table 3 .

The main constituents identified were cinnamaldehyde $(92.36 \%)$ in Cinnamomum sp.; eugenol $(91.94 \%)$ in E. caryophyllata; geraniol $(75.92 \%)$ in $C$. martini; pulegone $(68.96 \%)$ in $C$. verbenacea; geranial (58.89\%) followed by neral $(38.50 \%)$ in C. citratus; thymol $(33.72 \%)$ in T. vulgaris and trans- $\beta$-farnesene $(31.17 \%)$ in M. recutita.

The cytotoxic activity of essential oils in general is mostly due to the presence of phenols, aldehydes and alcohols (SACCHETTI et al., 2005). This fact was corroborated in the present study, which identified the major components of the three essential oils that 
presented most inhibition of germination. These were geranial and neral (aldehyde) in C. citratus; eugenol (phenol) in E. caryophyllata and geraniol (alcohol) in $C$. martini. In the literature, only the main compounds of some other essential oils, including eugenol, thymol, carvacrol, cinnamaldehyde, inter alia, have been studied. The minor constituents of the essential oils studied here could also have a relatively strong antimicrobial effect (BURT, 2004; BAKKALI et al., 2008), which can indicate that these molecules have synergism in antimicrobial activity. The synergistic effects of the diversity of major and minor compounds of the essential oils should be taken into consideration to account for their antimicrobial activity.

Table 1 - Inhibition of conidial germination of Pseudocercospora griseola strains 63-31 and 63-63 by essential oils tested at $0.5 \%, 0.1 \%$ and $0.02 \%$, in vitro.

\begin{tabular}{|c|c|c|c|c|c|c|}
\hline \multirow{4}{*}{ Essential oils } & \multicolumn{6}{|c|}{ Concentrations (\%) } \\
\hline & \multicolumn{2}{|c|}{0.5} & \multicolumn{2}{|c|}{0.1} & \multicolumn{2}{|c|}{0.02} \\
\hline & \multicolumn{2}{|c|}{ Strains } & \multicolumn{2}{|c|}{ Strains } & \multicolumn{2}{|c|}{ Strains } \\
\hline & $63-31$ & $63-63$ & $63-31$ & $63-63$ & $63-31$ & $63-63$ \\
\hline Cymbopogon citratus & 100.00 & 100.00 & 99.64 & 100.00 & 100.00 & 100.00 \\
\hline Cymbopogon martini & 99.29 & 100.00 & 98.93 & 100.00 & 99.64 & 99.48 \\
\hline Eugenia caryophyllata & 100.00 & 100.00 & 100.00 & 100.00 & 58.21 & 99.48 \\
\hline Cinnamoтит sp. & 100.00 & 100.00 & 98.93 & 99.48 & 51.79 & 98.43 \\
\hline Thymus vulgaris & 98.21 & 100.00 & 98.93 & 100.00 & 17.50 & 2.36 \\
\hline Matricaria recutita & 100.00 & 100.00 & 93.57 & 100.00 & 3.57 & 13.91 \\
\hline Cordia verbenacea & 98.93 & 99.48 & 94.64 & 96.33 & 4.29 & 10.24 \\
\hline Origanum vulgare & 100.00 & 100.00 & 86.79 & 87.40 & 0.36 & 11.81 \\
\hline Cymbopogon nardus & 100.00 & 100.00 & 83.21 & 89.50 & 6.79 & -36.48 \\
\hline Zingiber officinale & 99.29 & 100.00 & 50.71 & 95.28 & 1.79 & -35.43 \\
\hline Mentha arvensis & 99.64 & 100.00 & 35.71 & 99.48 & 14.29 & 59.58 \\
\hline Chamaecyparis pisifera & 100.00 & 100.00 & 21.79 & 78.48 & -0.71 & 25.98 \\
\hline Lavandula officinalis & 100.00 & 100.00 & 16.07 & 80.05 & 1.43 & 61.15 \\
\hline Ocimum basilicum & 97.86 & 100.00 & 26.79 & 57.48 & 26.79 & 36.48 \\
\hline Pimpinella anisum & 98.57 & 99.48 & 38.21 & 67.45 & 12.14 & 25.98 \\
\hline Ocimum selloi & 100.00 & 100.00 & 25.36 & 20.21 & 6.79 & 4.99 \\
\hline Baccharis dracunculifolia & 92.14 & 98.43 & 75.00 & 18.11 & 2.86 & 1.84 \\
\hline Laurus nobilis & 98.21 & 99.48 & 24.29 & 13.91 & 3.21 & -16.01 \\
\hline Citrus sinensis & 98.21 & 100.00 & 29.64 & -2.36 & 0.00 & -0.26 \\
\hline Melaleuca alternifolia & 95.36 & 96.85 & -3.21 & 7.61 & 1.07 & 47.51 \\
\hline Eucalyptus globulus & 86.43 & 94.23 & 2.14 & -7.61 & -1.43 & 6.56 \\
\hline Chamaecyparis plumosa & 45.36 & 98.95 & 2.14 & 6.04 & 3.21 & 50.66 \\
\hline Rosmarinus officinalis & 32.14 & 92.65 & -2.50 & -42.26 & 2.86 & -2.36 \\
\hline Lippia citriodora & 18.93 & 90.03 & 4.29 & 0.79 & -1.79 & -13.91 \\
\hline Corymbia citriodora & 18.57 & 34.38 & -2.14 & -5.51 & -1.43 & 38.06 \\
\hline Citrus limon & 0.36 & -35.96 & 0.36 & -35.96 & -0.71 & -50.13 \\
\hline
\end{tabular}




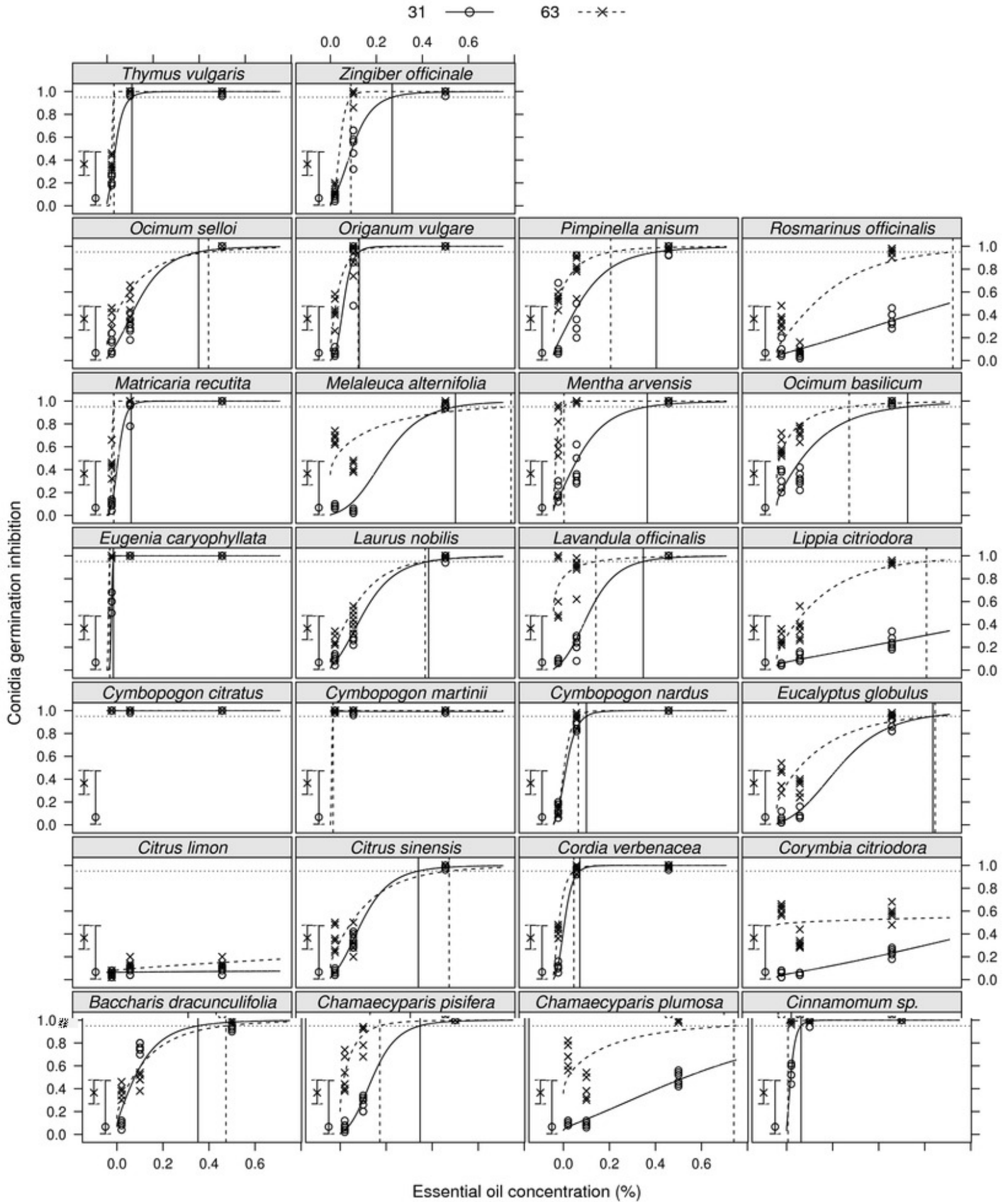

Figure 1 - Regression model fitted to data on number of germinated conidia. The dashed vertical lines represent the concentration that caused 95\% of inhibition in strains 63-31 and 63-63 of Pseudocercospora griseola. A 95\% confidence interval for the proportion of conidial germination in the control is represented along the regression curves. Points represent the proportion of germination observed. 
Table 2 - Estimation of coefficients of the logistic regression model for strains 63-31 and 63-63 of Pseudocercospora griseola treated with essential oils in vitro.

\begin{tabular}{|c|c|c|c|c|c|c|c|c|}
\hline \multirow{2}{*}{ Essential oils } & \multicolumn{4}{|c|}{ Strain 63-31 } & \multicolumn{4}{|c|}{ Strain 63-63 } \\
\hline & $\beta 0$ & $\beta 1$ & $\mathrm{c} 95 \% \mathrm{i}$ & p0.5 & $\beta 0$ & $\beta 1$ & $\mathrm{c} 95 \% \mathrm{i}$ & $\mathrm{p} 0.5$ \\
\hline Citrus limon & -2.73 & 0.23 & 587.39 & 0.07 & -2.69 & 1.35 & 17.49 & 0.07 \\
\hline Corymbia citriodora & -3.74 & 3.61 & 3.43 & 0.23 & -0.09 & 0.30 & 103.63 & 0.23 \\
\hline Lippia citriodora & -3.19 & 2.94 & 4.36 & 0.25 & -2.18 & 6.36 & 0.65 & 0.25 \\
\hline Rosmarinus officinalis & -3.44 & 3.98 & 2.57 & 0.35 & -2.52 & 6.25 & 0.76 & 0.35 \\
\hline Chamaecyparis plumosa & -3.31 & 4.55 & 1.89 & 0.48 & -0.57 & 4.09 & 0.74 & 0.48 \\
\hline Eucalyptus globulus & -4.98 & 9.62 & 0.68 & 0.86 & -1.77 & 5.69 & 0.69 & 0.86 \\
\hline Melaleuca alternifolia & -5.67 & 11.68 & 0.54 & 0.93 & -0.59 & 3.98 & 0.79 & 0.93 \\
\hline Ocimum basilicum & -2.32 & 6.98 & 0.57 & 0.93 & -0.71 & 6.52 & 0.31 & 0.93 \\
\hline Pimpinella anisum & -2.95 & 8.82 & 0.45 & 0.96 & -1.08 & 8.07 & 0.25 & 0.96 \\
\hline Laurus nobilis & -4.12 & 10.81 & 0.43 & 0.97 & -2.57 & 8.58 & 0.41 & 0.97 \\
\hline Mentha arvensis & -3.09 & 9.46 & 0.41 & 0.97 & -2.69 & 26.53 & 0.05 & 0.97 \\
\hline Baccharis dracunculifolia & -2.60 & 9.35 & 0.35 & 0.98 & -1.83 & 6.93 & 0.47 & 0.98 \\
\hline Citrus sinensis & -4.36 & 11.82 & 0.38 & 0.98 & -2.14 & 7.07 & 0.52 & 0.98 \\
\hline Lavandula officinalis & -4.98 & 12.70 & 0.39 & 0.98 & 0.07 & 6.70 & 0.18 & 0.98 \\
\hline Ocimum selloi & -3.99 & 11.00 & 0.40 & 0.98 & -1.79 & 7.14 & 0.44 & 0.98 \\
\hline Chamaecyparis pisifera & -5.21 & 13.84 & 0.35 & 0.99 & -1.37 & 10.39 & 0.17 & 0.99 \\
\hline Cymbopogon martini & 5.21 & -0.51 & 19.50 & 0.99 & -6.45 & 85.94 & 0.01 & 0.99 \\
\hline Cinnamomum sp. & -3.35 & 25.14 & 0.06 & 1.00 & 3.51 & 7.45 & 0.01 & 1.00 \\
\hline Cordia verbenacea & -5.41 & 24.72 & 0.11 & 1.00 & -3.16 & 20.57 & 0.09 & 1.00 \\
\hline Cymbopogon citratus & 6.30 & 1.42 & 5.56 & 1.00 & 22.63 & 0.00 & $*$ & 1.00 \\
\hline Cymbopogon nardus & -4.80 & 20.52 & 0.14 & 1.00 & -5.52 & 25.81 & 0.11 & 1.00 \\
\hline Eugenia caryophyllata & -14.09 & 102.78 & 0.03 & 1.00 & -6.45 & 85.94 & 0.01 & 1.00 \\
\hline Matricaria recutita & -6.26 & 28.48 & 0.10 & 1.00 & -15.81 & 110.48 & 0.03 & 1.00 \\
\hline Origanum vulgare & -6.27 & 26.02 & 0.13 & 1.00 & -2.42 & 15.41 & 0.12 & 1.00 \\
\hline Thymus vulgaris & -4.00 & 21.13 & 0.11 & 1.00 & -16.25 & 111.47 & 0.03 & 1.00 \\
\hline Zingiber officinale & -4.29 & 13.95 & 0.27 & 1.00 & -6.10 & 30.27 & 0.09 & 1.00 \\
\hline
\end{tabular}

*203654410150349486686208.00.

c95\% represents the concentration of essential oils that inhibited $95 \%$ of conidial germination. c95\% w was calculated as $p=\exp$ $\left(\beta_{0}+\beta_{1} \cdot \sqrt{ } c\right) / 1+\exp \left(\beta_{0}+\beta_{1} \cdot \sqrt{ } c\right)$.

p 0.5 is a percentage of germination inhibition estimated for doses of $0.5 \%\left(5000 \mu \mathrm{L}^{-L^{-1}}\right)$.

\section{Effect of essential oils on conidial ultrastructure}

Cymbopogon martini, C. citratus and $E$. caryophyllata were selected for further tests, in function of their potential for inhibiting germination of the pathogen's conidia at concentrations of $0.02 \%, 0.1 \%$ and $0.5 \%$, as observed in this experiment. When both $P$. griseola strains studied here (63-31 (Figure 2A) and 63-63 (Figure $3 \mathrm{~A})$ ) were treated with sterile water (control) the conidia kept the integrity of the cell wall, the plasma membrane, organized cytoplasm and some visible organelles, such as nucleus and mitochondria, showing well-defined envelopes. In contrast, conidia of both strains that were exposed to essential oils at $0.1 \%$ showed clear ultrastructural changes, which were observed by TEM.

The treatment of $P$. griseola conidia with C. martini essential oil revealed an altered cytoplasm, accompanied by a large empty area produced by previous cytoplasmic leakage (Figures 2B, 2D, 3B and 3C). Vacuolisation was also frequently noted (Figures $2 \mathrm{C}$ and $3 \mathrm{C}$ ) and electrondense aggregates covering parts of the wall and of the condensed cytoplasm (Figures 2C and 2D) respectively. 
Breakage of the plasma membrane and wall was caused in this conidium (Figure 3C). The accumulation of electrondense material characterized by an electron dark image, due to the contact with osmium, can indicate penetration by the essential oil. Some mitochondria underwent extensive disruption of the internal structure, with a decrease in the mitochondrial cristae (Figures 2B, 2C, 3B, 3C).

In conidia treated with $C$. citratus essential oil, increased cytoplasmic condensation and aggregation was noted (Figures 2E and 3D). It was also possible to see massive vacuolation of the cytoplasm with vacuole fusion, disruption of the internal mitochondrial structure (Figures $2 \mathrm{E}, 2 \mathrm{~F}$ and $3 \mathrm{D}$ ), large empty spaces caused by absence of the cytoplasmic matrix and lysis of membranous organelles (Figures 2E, 2F, 2G, 3D and 3E) and electron-dense compounds over the aggregated cytoplasm, mitochondria and wall (Figures 2E, 2F and 3D). Rupture of the plasma membrane and wall was observed (Figure 3E), and the wall appeared thinner than normal. The cytoplasm in this conidium was quite disorganized.

Table 3 - Chemical composition of essential oils with antifungal activity of more than $90 \%$ on germination of strains 63 31 and 63-63 of Pseudocercospora griseola, when tested at $0.1 \%$.

\begin{tabular}{|c|c|c|c|c|c|c|c|}
\hline Contents & $\begin{array}{l}\text { Thymus } \\
\text { vulgaris }\end{array}$ & $\begin{array}{c}\text { Cordia } \\
\text { verbenacea }\end{array}$ & $\begin{array}{l}\text { Cymbopogon } \\
\text { citratus }\end{array}$ & $\begin{array}{c}\text { Eugenia } \\
\text { caryophyllata }\end{array}$ & $\begin{array}{l}\text { Matricaria } \\
\text { recutita }\end{array}$ & $\begin{array}{c}\text { Cymbopogon } \\
\text { martini }\end{array}$ & $\begin{array}{c}\text { Cinnamomum } \\
\text { sp. }\end{array}$ \\
\hline benzaldehyde & - & - & - & - & - & - & 0.28 \\
\hline$\alpha$-bisabolol oxide A & - & - & - & - & 17.77 & - & - \\
\hline$\alpha$-bisabolol oxide B & - & - & - & - & 10.43 & - & - \\
\hline bornyl acetate & - & - & - & - & - & - & 0.93 \\
\hline camphene & 1.62 & - & - & - & - & - & - \\
\hline chamazulene & - & - & - & - & 9.29 & - & - \\
\hline cinnamaldehyde & - & - & - & - & - & - & 92.36 \\
\hline cinnamyl acetate & - & - & - & - & - & - & 1.48 \\
\hline$\alpha$-copaene & - & - & - & - & - & - & 0.29 \\
\hline 1,8-cineole & - & - & - & - & - & - & 1.05 \\
\hline eugenol & - & - & - & 91.94 & - & - & - \\
\hline trans- $\beta$-farnesene & - & - & - & - & 31.17 & - & - \\
\hline $\begin{array}{l}\text { trans, trans- } \alpha- \\
\text { farnesene }\end{array}$ & - & - & - & - & 2.18 & - & - \\
\hline geranial & - & - & 58.89 & - & - & 13.72 & - \\
\hline geraniol & - & - & 2.61 & - & - & 75.92 & - \\
\hline$\alpha$-humulene & - & - & - & 1.51 & - & - & - \\
\hline hydrocinnamaldehyde & - & - & - & - & - & - & 0.66 \\
\hline isoborneol & 3.45 & - & - & - & - & - & - \\
\hline limonene & - & - & - & - & - & - & 0.29 \\
\hline menthone & - & 14.17 & - & - & - & - & - \\
\hline neral & - & - & 38.50 & - & - & 5.71 & - \\
\hline neryl acetate & - & - & - & - & - & 4.65 & - \\
\hline$\alpha$-pinene & - & - & - & - & - & - & 0.54 \\
\hline$\beta$-pinene & - & - & - & - & - & - & 0.10 \\
\hline pulegone & - & 68.96 & - & - & - & - & - \\
\hline sabinene & 0.95 & - & - & - & - & - & - \\
\hline terpinen-4-ol & - & - & - & - & - & - & 0.28 \\
\hline$\alpha$-terpineol & - & - & - & - & - & - & 1.04 \\
\hline thymol & 33.72 & - & - & - & - & - & - \\
\hline not identified & 60.26 & 16.87 & - & 6.55 & 29.16 & - & 0.70 \\
\hline
\end{tabular}

Content of constituents was determined from a peak relative to the total area in GCMS analysis. 

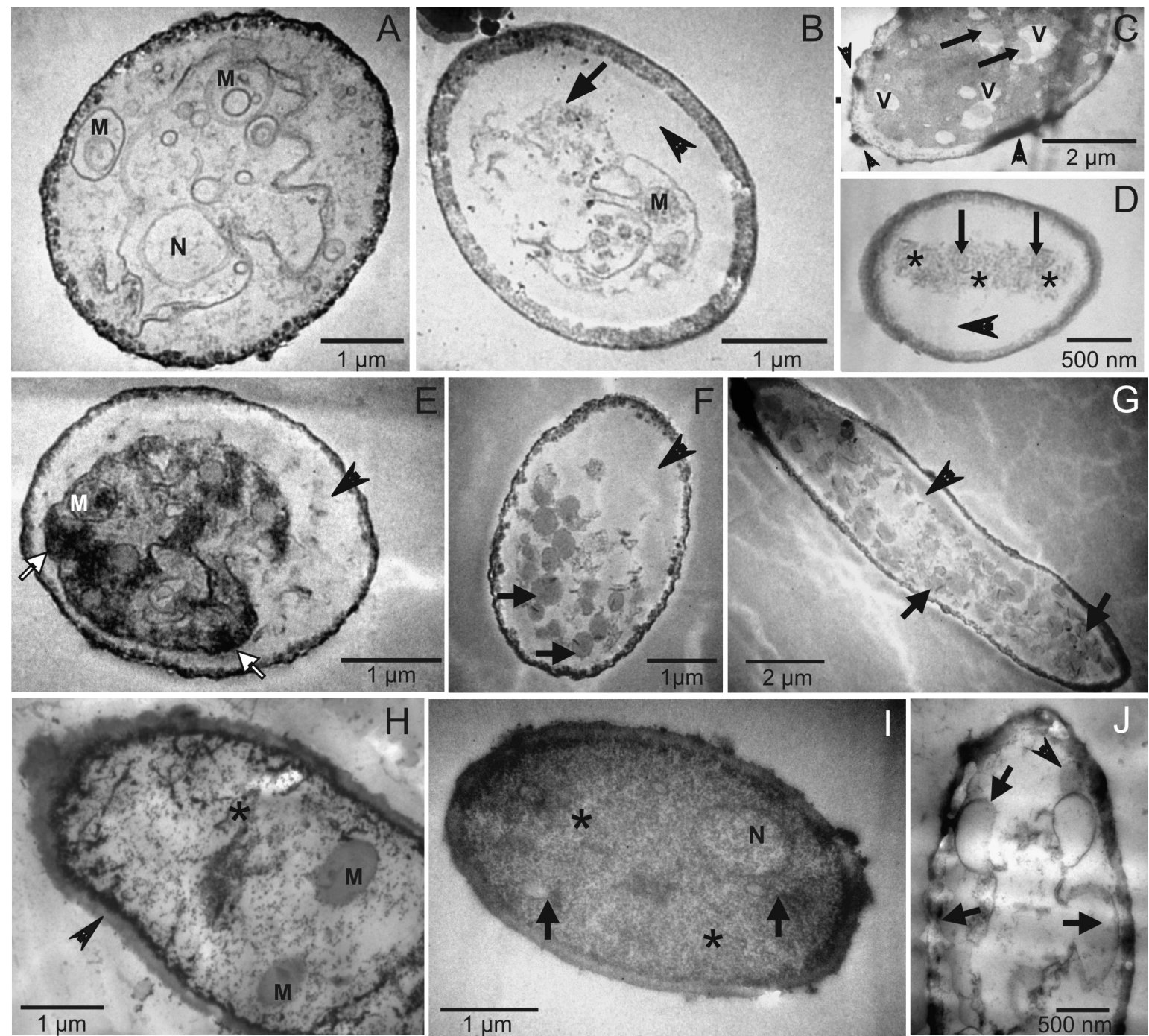

Figure 2 - Transmission electron micrographs of effect of essential oils (EO) at $0.1 \%$ on ultrastructure of Pseudocercospora griseola conidia, strain 63-31. A, Control, mitochondria (M), nucleus (N). B to D, treatment with Cymbopogon martini EO. B, the degraded cytoplasm (arrow), a large empty area (arrowhead) and mitocondria (M) are shown. C, condensation of cytoplasm, some vacuoles (V), mitochondria (arrows) and electron-dense material over the wall (arrowheads) are observed. D, electron-dense aggregates (asterisks) and large empty space are visible (arrowhead), and some organelles are not recognizable (arrows). E to G, treatment with Cymbopogon citratus EO. E, condensation of cytoplasm and electron-dense material (arrows), empty area (arrowhead), mitochondria (M) were visible. F and G, a large empty space (arrowheads) and numerous mitochondria with narrow bands of electron-dense compounds (arrows) are shown. H to J, treatment with Eugenia caryophyllata EO. H, the area in the wall appears with higher contrast (arrowhead), electron-dense aggregates (asterisk) and mitochondria (M) are observed. I, the nucleus is still visible (N) and other organelles are not well distinguished (arrows). Electron-dense aggregates (asterisks) appeared covering all conidia. J, plasmalema retraction (arrows), mitochondria-like organelle (arrowhead), electron-dense material over the wall are observed in this conidium. 

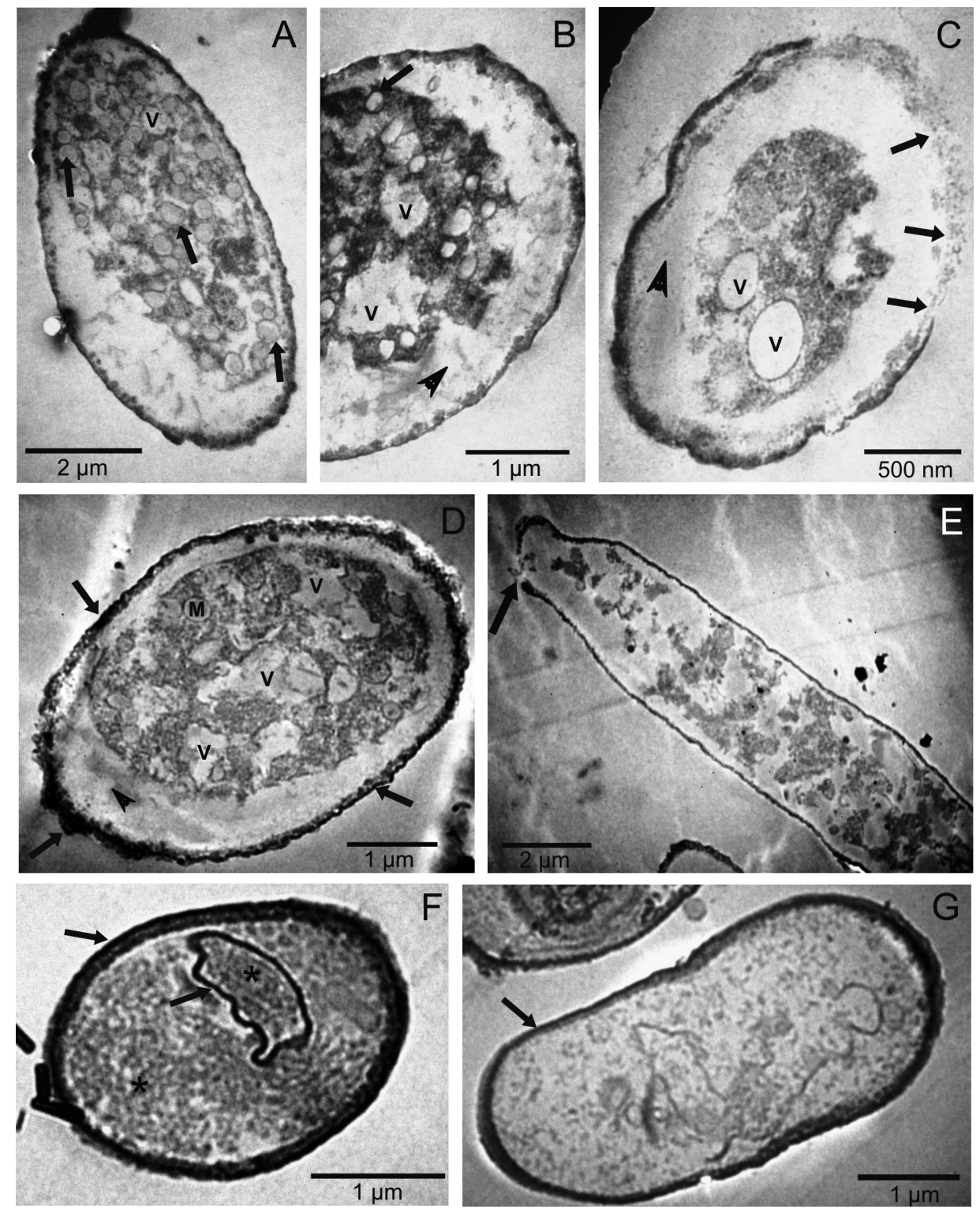

Figure 3 - Transmission electron micrographs of effect of essential oils (EO) at $0.1 \%$ on ultrastructure of Pseudocercospora griseola conidia, strain 63-63. A, Control, showing numerous mitochondria (arrows), vacuole (V). $\mathrm{B}$ and $\mathrm{C}$, treatment with Cymbopogon martini EO. B, the cytoplasm is still visible and condensed but most organelles are affected as mitochondria (M); some vacuoles (V) are at times observed within electron-dense material. A large empty area (arrowhead) is shown. C, this conidium is altered; the organelles are difficult to distinguish. Some vacuoles (V), plasma membrane breakage (arrows) and (arrowhead) a large empty area is observed. D and E, treatment with Cymbopogon citratus EO. D, in this conidium the condensed cytoplasm, mitochondria (M), vacuoles (V), empty area (arrowhead) and electron-dense compounds (arrows) over the wall are visible. E, in this probably unviable conidium the organelles are not recognizable and the plasma membrane is broken (arrow). F and G, treatment with Eugenia caryophyllata EO. F, electron-dense material over the wall and envelope of organelle, and what appears to be the nucleus is observed (arrows). Electron-dense aggregates (asterisks) appeared covering all conidia. G, electron-dense compounds over the wall and remains of organelles and/or cytoplasmic material are shown. 
E. caryophyllata essential oil caused disorganization of the cytoplasm, plasmalema retraction, undulation, and invagination in the treated conidia (Figure 2J). Electron-dense material appeared covering all conidia (Figures $2 \mathrm{I}$ and $3 \mathrm{~F}$ ), and over the wall (Figure $3 \mathrm{~F})$.

It should be emphasized that most of this damage is irreversible, and the changes showed general disorganization of the cytoplasm, as well as cytoplasm leakage, probably caused by loss of conidial membrane integrity, which could eventually lead to fungal cell death. These studies allow us to observe the complexity of the composition of essential oils, and to suggest that this complexity implies that there are multiple mechanisms of action. The mode of action of essential oils commonly affects several targets at the same time, and no particular resistance or adaptation to essential oils has been described (CARSON et al., 2002; BAKKALI et al., 2008). In this regard, Denyer (1990) affirms that leakage of intracellular material is a general phenomenon provoked by many antimicrobial substances. Cell death may have been the result of the extensive loss of cell contents, the exit of critical molecules and ions, and the initiation of autolysis. Besides this, the permeabilization of outer and inner mitochondrial membranes leads to cell death by apoptosis and necrosis (ARMSTRONG, 2006). It may be that chain reactions from the wall or the outer cell membrane invade the whole cell, through the membranes of different organelles, such as mitochondria and peroxisomes (BAKKAKLI et al., 2008). In this study this membrane permeability was confirmed by observations made under transmission electron microscopy and by the high germination inhibition seen in treated conidia.

The antifungal activity of at least $93 \%$ in conidia treated with Cinnamomum sp., E. caryophyllata, M. recutita, $C$. verbenacea, $T$. vulgaris, $C$. citratus and $C$. martini at $0.1 \%$ corroborates similar studies carried out in several other pathosystems. In these, inhibition of germination or mycelial growth caused by pure essential oils, or by one or more of their constituents identified as major in this study (Table 3), could be noted on applying different concentrations and in various forms (WILSON et al., 1997; KASALI et al., 2001; SAIKIA et al., 2001; PARANAGAMA et al., 2003; KISHORE et al., 2007; DE OLIVEIRA et al., 2010; BASSOLÉ et al., 2011; KHAN; AHMAD, 2011). Control of $P$. griseola using essential oils, however, is reported here for the first time.

Other important observations made in this work, were a discontinuous and highly undulating plasma membrane, and extensive disruption of the internal mitochondrial structure with a decrease in the cristae, which can indicate severely altered membranes in both strains of $P$. griseola exposed to essential oils. According to detailed research into membrane permeability (SIKKEMA et al., 1995; VERCESI et al., 1997), some chemical constituents of essential oils, such as typical lipophiles, can pass through the cytoplasmic wall and membrane, disrupt the structure of their different layers of polysaccharides, fatty acids and phospholipids and permeabilize them. Cytotoxicity appears to include such membrane damage. In eukaryotic cells, essential oils can provoke depolarisation of the mitochondrial membranes by decreasing the membrane potential, affecting $\mathrm{Ca} 2+$ ion cycling.

Transmission electron microscopy was seen to be a useful tool to elucidate the effects of $C$. martini, $C$. citratus and E. caryophyllata essential oil at $0.1 \%$ on conidia of $P$. griseola strains. It was observed that changes that occurred in the ultrastructure of this pathogen corroborate findings by several researchers in other pathosystems, as reported in (ROZWALKA et al., 2010; RASOOLI et al. 2006; TIAN et al., 2012; AVIS et al., 2009). Scanning and transmission electron microscopy examinations reveal ultrastructural alterations in several compartments of the cell, such as plasma membrane, cytoplasm (swelling, shrivelling, vacuolations, leakage) and nucleus (SOYLU et al., 2006; SANTORO et al., 2007; TYAGI; MALIK, 2010, DAN et al., 2010).

The determination of the biological activity of secondary metabolites from medicinal plants, with respect to direct antimicrobial activity or by activating defense mechanisms of the treated plants, as well as fractionation and identification of these metabolites, may help researchers gain more knowledge to improve their use as an alternative method for plant disease control (STANGARLIN et al., 1999). According to Riefler et al. (2009), considering the multiple biological activities of essential oils and of their chemical constituents, further research involving product formulations and effective blends and doses of isolated compounds should be performed, with the aim of protecting plants efficiently without exerting phytotoxic side-effects.

\section{CONCLUSIONS}

Fungitoxic potential is related to the chemical composition of the essential oil, as well as to the sensitivity of the pathogen to one or more constituents in different amounts. 
The identification of secondary metabolites in the essential oils with antifungal activity constitutes a useful tool for the synthesis of new products by the chemical industry.

The direct fungitoxic action of several essential oils caused damage to cellular ultrastructure, consequently invalidating the germination of $P$. griseola; it presents a promising alternative for the control of angular leaf spot in bean and represents less risk to human health and the environment.

\section{ACKNOWLEDGMENTS}

The authors thank Dr. Claudia Regina G. Labory (Pos-Doctor in Department of Soil Science, Federal University of Lavras, Campus Universitário, 3037, CEP 37200000, Lavras, MG, Brazil) for her assistance and technical support in TEM and M.S. Cassius Nonato S. Freire (master student at Biology Department-Ufla) for help with the pathogen strains. Also, we acknowledge the doctoral scholarship and financial support granted by the Coordenação de Aperfeiçoamento de Pessoal de Nível Superior (CAPES), Conselho Nacional de Desenvolvimento Científico e Tecnológico $(\mathrm{CNPq})$ for a productivity grant for the second author and the Fundação de Amparo à Pesquisa de Minas Gerais (FAPEMIG) for financial support to the Laboratory of Electron Microscopy and Ultrastructural Analysis at the Federal University of Lavras, MG, Brazil.

\section{REFERENCES}

ARMSTRONG, J.S. Mitochondrial membrane permeabilization: the sine qua non for cell death. BioEssays, Cambridge, v.28, p.253-260. 2006.

AVIS, T.J. et al. Ultrastructural alterations in Fusarium sambucinum and Heterobasidion annosum treated with aluminum chloride and sodium metabisulfite. Phytopathology, Saint Paul, v.99, n.2, p.167-175. 2009.

BAKKALI, F. et al. Biological effects of essential oils: a review. Food and Chemical Toxicology, Orlando, v.46, p.446-475. 2008.

BÅNG, U. Screening of natural plant volatiles to control the potato (Solanum tuberosum) pathogens Helminthosporium solani, Fusarium solani, Phoma foveata and Rhizoctonia solani. Potato Research, New York,v.50, p.185-203. 2007.
BARRERA-NECHA, L.L. et al. Efficacy of essential oils on the conidial germination, growth of Colletotrichum gloeosporioides (Penz.) Penz. and Sacc and control of postharvest diseases in papaya (Carica papaya L.). Plant Pathology, London, v.7, p.174-178. 2008.

BASSOLÉ, I.H.N.et al. Chemical composition and antimicrobial activity of Cymbopogon citratus and Cymbopogon giganteus essential oils alone and in combination. Phytomedicine, Stuttgart, v.18, p.1070 1074. 2011.

BONALDO, S.M. et al. Fungitoxicidade, atividade elicitora de fitoalexinas e proteção de pepino contra Colletotrichum lagenarium pelo extrato aquoso de Eucalyptus citriodora. Fitopatolgia Brasileira, Viçosa, v.29, p.128-134. 2004.

BROCK, R.D. Resistance to angular leaf spot among varieties of beans. Journal of the Australian Institute of Agricultural Science, Sydney, v. 17, p.25-30. 1951.

BURT, S. Essential oils: their antibacterial properties and potential applications in foods - a review. International Journal of Food Microbiology, Amsterdam, v.94, p.223253.2004

CARSON, C.F., MEE, B.J., RILEY, T.V. Mechanism of action of Melaleuca alternifolia (tea tree) oil on Staphylococcus aureus determined by time-kill, lysis, leakage and salt tolerance assays and electron microscopy. Antimicrobial Agents and

Chemotherapy, Washington DC, v.46, p.1914-1920. 2002.

CHRISTIAN, E.J., GOGGI, A.S. Aromatic plant oils as fungicide for organic corn production. Crop Science, Madison, v.48, p.1941-1951. 2008.

DAMASCENO-SILVA, K.J. et al. Pathogenic variability of isolates of Pseudocercospora griseola, the cause of common bean angular leaf spot, and its implications for resistance breeding. Journal of Phytopathology, Berlín, v.156, n.10, p.602-606, 2008.

DAN, Y. et al. Activities of essential oils from Asarum heterotropoides var. mandshuricum against five phytopathogens. Crop Protection, London, v.29, p.295299. 2010. 
DENYER, S.P. Mechanisms of action of biocides. International Biodeterioration, Barking, v.26, p.89-100. 1990.

DE OLIVEIRA, M.M.M. et al. Disinfectant action of Cymbopogon sp. essential oils in different phases of biofilm formation by Listeria monocytogenes on stainless steel surface. Food Control, Vurrey, v.21, p.549553. 2010 .

FIORI, A.C.G. et al. Antifungal activity of leaf extracts and essential oils of some medicinal plants against Didymella bryoniae. Journal of Phytopathology, Berlin, v.148, p.483-487. 2000.

GHINI, R., KIMATI, H. Resistência de fungos a fungicidas. Jaguariúna: Embrapa Meio Ambiente. 2000. $78 \mathrm{p}$.

ISMAN, M. B. Plant essential oils for pest and disease management. Crop Protection, London, v.19, p.603- 608. 2000.

JESUS-JÚNIOR, W.C. et al. Effects of angular leaf spot and rust on yield loss of Phaseolus vulgaris. Phytopathology, Saint Paul, p.1045-1053. 2001.

KASALI, A.A., OYEDEJ, A.O., ASHILOKUN, A.O. Volatile leaf oil constituents of Cymbopogon citratus (DC) Stapf. Flavour and Fragrance Journal, Malden, v.16, p.377-378. 2001.

KHAN, M.S.A., AHMAD, I. In vitro antifungal, antielastase and anti-keratinase activity of essential oils of Cinnamomum, Syzygium and Cymbopogon-species against Aspergillus fumigatus and Trichophyton rubrum. Phytomedicine, Stuttgart, v.19, n.1, p.48-55. 2011.

KISHORE, G.K., PANDE, S., HARISH, S. Evaluation of essential oils and their components for broad-spectrum antifungal activity and control of late leaf spot and crown rot diseases in peanut. Plant Disease, Saint Paul, v.91, p.375-379. 2007.

KOTZEKIDOU, P., GIANNAKIDIS, P., BOULMATIS A., Antimicrobial activity of some plant extracts and essential oil against foodborn pathogens in vitro and on the fate of inoculated pathogens in chocolate. LWT Food Science and Technology, London, v.41, n.1, p.119127. 2008.

LEE, S.O. et al. Antifungal activity of five plant essential oils as fumigant against postharvest and soilborne plant pathogenic fungi. Plant Pathology, London, v.23, p.97102.2007.

MIHALIAK, C.A., GERSHENZO, J., CROTEAU, R. Lack of rapid monoterpene turnover in rooted plants, implications for theories of plant chemical defense. Oecologia, Berlin, v.87, p.373-376. 1991.

MIKLAS, P.N. et al. Common bean breeding for resistance against biotic and abiotic stresses: From classical to MAS breeding. Euphytica, Wageningen, v.147, p.105-131. 2006.

OROZCO, S., ARAYA, C.M. Variabilidade patogênica de Phaeoisariopsis griseola na Costa Rica. Fitopatologia Brasileira, Viçosa, v.30, p.589-593. 2005.

NIETSCHE, S. et al. Genetic diversity of Phaeoisariopsis griseola in the state of Minas Gerais, Brazil. Euphytica, Wageningen, v.117, n.1, p. 77-84, 2001.

PARANAGAMA, P.A. et al. Fungicidal and antiaflatoxigenic effects of the essential oil of Cymbopogon citratus (DC.) Stapf. (lemongrass) against Aspergillus flavus Link. isolated from stored rice. Letters in Applied Microbiology, Oxford, v.37, p.86-90. 2003.

PASTOR-CORRALES, M.A., JARA, C., SINGH, S. Pathogenic variation in, source of, and breeding for resistance to Phaeoisariopsis griseola causing angular leaf spot in common bean. Euphytica, Wageningen, v.103, p.161-171. 1998.

PAULA-JÚNIOR, T.J., ZAMBOLIM, L. Doenças, In: VIEIRA, C., PAULA-JÚNIOR, T.J., BORÉM, A. (Eds.), Feijão. Viçosa-UFV, 2006. p.359-414.

PEREIRA, R.B. et al. Potential of essential oils for the control of brown eye spot in coffee plants. Ciência e Agrotecnologia, Lavras, v.35, n.1, p.115-123. 2011. 
PYNDJI, M.M. Pathogenic variability of

Phaeoisariopsis griseola in the Great Lakes region, in: PAN African Bean Pathology Working Group Meeting 1992. Thinka, Kenya, CIAT, African Workshop Series 23, 1993.

QUINTANILLA, P., ROHLOFF, J., IVERSEN, T.H. Influence of essential oils on Phytophthora infestans. Potato Research, New York, v.45, p.225235. 2002.

RASOOLI, I., REZAEI, M.B., ALLAMEH, A. Growth inhibition and morphological alterations of Aspergillus niger by essential oils from Thymus eriocalyx and Thymus $x$-porlock. Food Control, Vurrey, v.17, p.359364. 2006.

REYNOLDS, E.S. The use of lead citrate at high $\mathrm{pH}$ as an electronopaque stain in electron microscopy. The Journal of Cell Biology, New York, v.17, p.208-212. 1963.

RIEFLER, J; NOVAK, J; KOSCHIER, EH. Components of essential oils in plant protection. Zeitschrift für Arznei- Gewürzpflanzen, Clenze, v.14, n.2, p.70-76. 2009.

ROZWALKA, L.C., ALVES, E., AMARAL, D.C. Ultrastructural study of conidia of Colletotrichum gloeosporioides and Colletotrichum musae treated with essential oils. Interciencia, Caracas, v.35, p.912915. 2010.

SACCHETTI, G. et al. Comparative evaluation of 11 essential oils of different origin as functional antioxidants, antiradicals and antimicrobials in food. Food Chemistry, Barking, v.91, 621-632.2005.

SAIKIA, D. et al. Comparative anti-fungal activity of essential oils and constituents from three distinct genotypes of Cymbopogon spp. Current Science, Bangalore, v.80, p.1264-1266. 2001.

SANTORO, G.F. et al. Effect of oregano (Origanum vulgare L.) and thyme (Thymus vulgaris L.) essential oils on Trypanosoma cruzi (Protozoa:

Kinetoplastida) growth and ultrastructure. Parasitology Research, Berlin, v.100, p.783-790. 2007.
SARTORATO, A., RAVA, C.A. Principais doenças do feijoeiro comum e seu controle. Brasília: Embrapa - SPI. 211-242. 1994.

SCHWAN-ESTRADA, KR.F. Potencial de extratos e óleos essenciais de vegetais como indutores de resistência - plantas medicinais. Summa Phytopathologica, Botucatu, v.29, p.124-125. 2003.

SHAHI, S.K. et al. Use of essential oil as botanicalpesticide against post harvest spoilage in Malus pumilo fruit. BioControl, Dordrecht,v. 48, p. 223-232, 2003.

SIKKEMA, J., DE BONT, J. A. M., POOLMAN, B., Mechanisms of membrane toxicity of hydrocarbons. Microbiological Reviews, Washington DC, v.59, p.201222.1995.

SILVA, K.J.D. et al. Pathogenic variability of isolates of Pseudocercospora griseola, the cause of common bean angular leaf spot, and its implications for resistance breeding. Journal of Phytopathology, Berlin, v.156, p.602606. 2008.

SOYLU, E.M., SOYLU, S., KURT, S. Antimicrobial activity of the essential oils of various plants against tomato late blight disease agent Phytophthora infestans. Mycopathologia, The Hague, v.161, p.119-128. 2006.

STANGARLIN, J.R. et al. Plantas medicinais e controle alternativo de fitopatógenos. Biotecnologia Ciência \& Desenvolvimento, Brasília, v.11, p.16-21. 1999.

STENGLEIN, S. et al. Angular leaf spot: a disease caused by the fungus Phaeiosariopsis griseola (Sacc.) Ferraris on Phaseolus vulgaris L. Advances in Applied

Microbiology, New York, v.52, p.209-243. 2003.

STENGLEIN, S.A., BALATTI, P.A. Genetic diversity of Phaeoisariopsis griseola in Argentina as revealed by pathogenic and molecular markers. Physiological and Molecular Plant Pathology, London, v.68, p.158-167. 2006.

TIAN, J. et al. The control of Aspergillus flavus with Cinnamomum jensenianum Hand.-Mazz essential oil and its potential use as a food preservative. Food Chemistry, Barking, v.130, p.520-527. 2012. 
TYAGI, A.K., MALIK, A., In situ SEM, TEM and AFM studies of the antimicrobial activity of lemon grass oil in liquid and vapour phase against Candida albicans.

Micron, Oxford, v.41, p.797-805. 2010.

VERCESI, A.E. et al. The role of reactive oxygen species in mitochondrial permeability transition. Bioscience

Reports, New York, v.17, p.43-52. 1997.
WILSON, C.L. et al. Rapid evaluation of plant extracts and essential oils for antifungal activity against Botrytis cinerea. Plant Disease, St. Paul, v.81, p.204210. 1997.

ZAMBONELLI, A. et al. Effects of essential oils on phytopathogenic fungi in vitro. Journal of Phytopathology, Berlin, v.144, p.491-494. 1996.

Ciênc. agrotec., Lavras, v. 36, n. 3, p. 270-284, maio/jun., 2012 